\title{
THE RELATION BETWEEN CARDIAC. SIZE AND CARDIAC OUTPUT PER MINUTE FOLLOWING THE ADMINIS- TRATION OF DIGITALIS IN NORMAL DOGS
}

\author{
BY ALFRED E. COHN AND HAROLD J. STEWART \\ (From the Hospital of the Rockefeller Institute for Medical Research, New York)
}

(Received for publication June 25, 1928)

The nature of the action of digitalis continues to be an object of searching enquiry in the clinic although there is no longer any doubt in the minds of experienced clinical observers that its use in many situations is beneficial. What mechanism in the heart is responsible for the beneficial action that is so often observed, is, in practically all instances other than in fibrillation of the auricles, unknown. One difficulty in understanding its behavior consists in the confusion that arises in the attempt to harmonize the results of clinial observation with those of pharmacological analysis. The problem of what are to be considered beneficial effects is still far from being adequately stated or from being properly solved. What in short are the objects of digitalis therapy?

The experiments which Harrison and Leonard (1926) and the observations which Burwell, Neighbors and Regen (1927) have recently published are the occasion for further reflection on this matter. The observation that soon after the administration of digitalis, the volume output of the heart per minute diminishes was new and unexpected. It seemed to require revision of current views. It had been the accepted belief that in heart failure when edema was present, the volume output from the heart declined, and that improvement consisted in restoring this amount to the original level. Under these circumstances, to prescribe digitalis which, it was now clear, also depresses the volume output, appeared logically to be mistaken practise. .Harrison and Leonard accepted this situation as if all the facts involved in it were known and proceeded to draw farreaching inferences from their observations. The inferences included not only deductions on the action of digitalis itself and a change in its 
classification from stimulant to depressant, but involved its use in heart disease and in such diseases as pneumonia in which many observers believed it to be beneficial.

It soon appeared that in the new situation there were difficulties which it was impossible to ignore. Some of them it seemed possible to explore. They are questions such as these: Is the effect of digitalis in decreasing the volume output transient, as in Harrison and Leonard's dogs, or prolonged, as it appears to be in Burwell, Neighbors and Regen's patients; is it the same in animals with hearts of normal size and in animals the hearts of which are enlarged; does it make a difference whether the hearts are merely enlarged or does the presence of disease of the muscle also play a rôle in the final effect; does the presence of edema of the skin, tissues, and organs make a difference? If in all these situations digitalis behaves alike, is there perhaps a difference between dogs and man in the response to digitalis under any or all the heads which have been mentioned? And finally, in the interests of clearness, is the classification of digitalis as a depressant correct, and on which of its essential actions does the inference depend which places it in this category?

There is another matter of great interest which arises in connection with the studies of Harrison and Leonard. It concerns the definition of beneficial action and how its presence is to be ascertained. Shall beneficial action depend on the a priori assumption that it can be recognized and can be appraised in terms of one or another detailed effect of this drug, such as its effect on the blood pressure or the volume output or its effect on tone or on contraction or another of the many actions which it undoubtedly possesses? Or is it to depend on the net result of all these, on the general reaction of the whole man. The matter is one really of great difficulty in connection with the circulation. If digitalis, for instance, slowed the rate of the ventricles in auricular fibrillation but failed to relieve the patient permanently of whatever general disability affected him, would its use be continued even in the absence of a substitute? Examples like this may of course be multiplied. This one is suggested to illustrate the point at issue, namely, whether beneficial action can without searching analysis be equated with any one of the details of the action of an agent, especially when it is scarcely known whether 
that action is conspicuously representative of the process, viewed in its entirety, which is present. In this case, the function in question is the volume output and the rôle it plays in heart failure. Enough evidence on precisely what the course of this phenomenon in heart disease is can scarcely be said to have been accumulated. To decide that volume output may be used as an index of the degree of heart failure is therefore premature.

These are the aspects of the problem of the action of digitalis from which we have planned our experiments. They deal with certain phases of its effects only. Their limited applications in the clinic will be evident. They have we think the advantage of having been conducted in animals free from anesthetics and from operative disturbance.

\section{METHODS}

The subjects of these experiments were normal intact dogs. Anesthetics were not used. They were trained to breathe in a Benedict spirometer before the beginning of these experiments until they were able to do so quite naturally. It required practice for no more than 20 to 30 minutes a day for 10 days to two weeks to accomplish this result. At the end of this time they lay quietly during estimations of oxygen consumption without emotional disturbance. The rubber mask described by Blalock (1927) was used and found to be satisfactory.

The dogs were in a basal metabolic state on the days the estimations of cardiac output were made. Samples of arterial blood were drawn from a femoral artery and those of mixed venous blood from the right ventricle by means of a cannula inserted into that chamber through the right external jugular vein (Stewart, 1925). The skin over the vein was anesthetized locally with 2 per cent novocain solution and the operation was carried out aseptically. The oxygen content of these samples was estimated by the Van Slyke and Neill (1924) manometric method. The difference between the oxygen content of the arterial and of the mixed venous blood gives the amount of oxygen removed from the blood by the tissues, or from the point of view of the lesser circulation, the amount of oxygen taken up by the blood in passing through the lungs. Immediately after the samples of blood were drawn the oxygen consumption was measured with a Benedict spirometer equipped with a graphic recording drum.

Data were therefore at hand for calculating the cardiac output according to the principle of Fick (1870):

$$
\begin{aligned}
& \text { cubic centimeters of oxygen removed per minute }=\text { cubic centimeters of } \\
& \text { amount of oxygen absorbed by } 1 \text { cubic centimeter }=\text { cubic centimeters of } \\
& \text { of blood in passing through the lungs } \\
& \text { the lungs per minute }
\end{aligned}
$$


To study the effect of digitalis upon contraction of cardiac muscle we made use of the method of photographing the motion of points of the heart's borders by casting shadows of these points made by roentgen rays upon moving films. We adapted for dogs the apparatus which Cohn and Stewart (1924) devised formerly

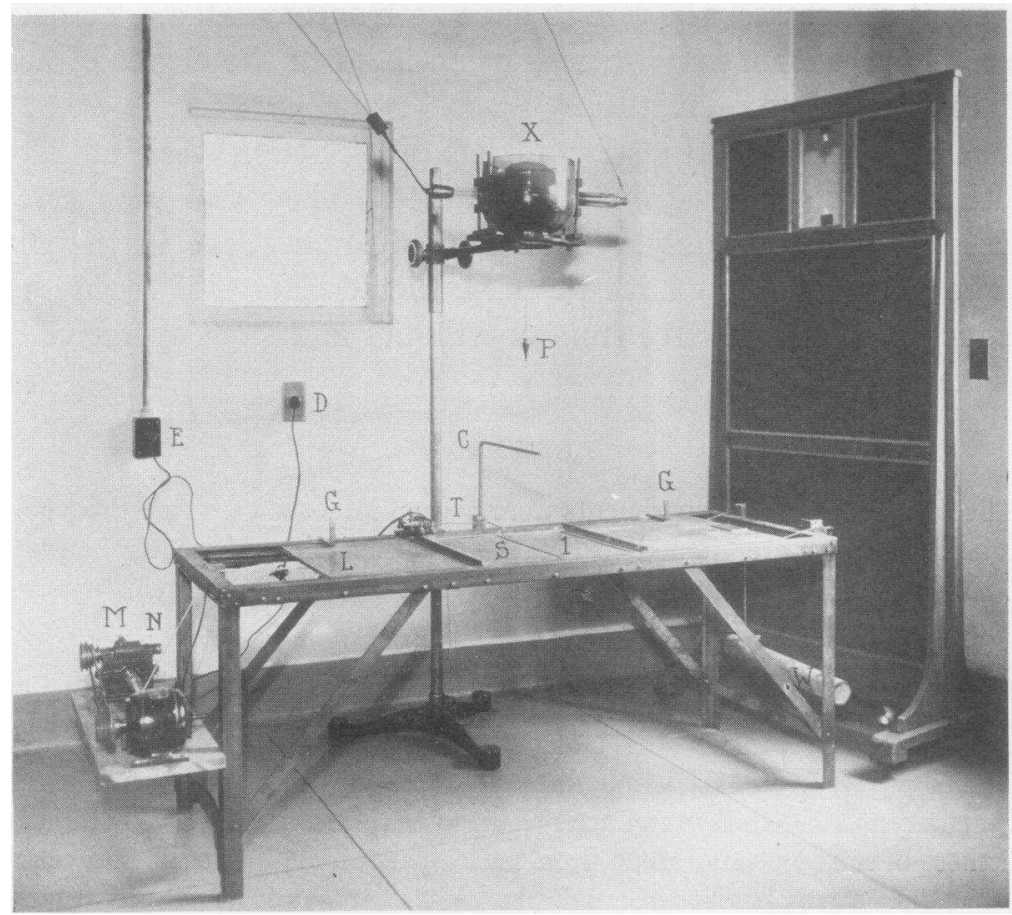

Fig. 1. Photograph of the Apparatus Used in Making Moving X-ray PHOTOGRAPHS OF THE HEART

See figure 2 for a diagrammatic sketch of the apparatus. $X, \mathrm{x}$-ray tube 34 inches from control film; $P$, plumb line for centering x-ray tube over slit $S$; $C$, rod to indicate location of slit $S$; $T$, electromagnetic time marker from Petzold clock; $G$, guide for $\operatorname{dog}$ board; $D$, switch to Petzold clock; $E$, current switch to motor $M$; $L$, lead screen; $S, 0.5 \mathrm{~cm}$. slit in the lead screen; 1 , guides for control film; $W$, counter-weight; $N$, cable for drawing moving film past the slit; $M$, motor.

for human beings. The photographic system instead of being vertical now functioned horizontally. The dogs lay on a proper board. This was placed upon a lead screen (fig. 1 and $2, L$ ) in which a transverse slit (fig. 1 and 2, S) was cut $0.5 \mathrm{~cm}$. wide. Opposite the slit near one end a time recording lever (fig. 1,T) 
was placed, consisting of the armature of a magnet in series with a Petzold clock. The dog board (fig. 2, B) was movable on the lead screen so that the portion of the border of the left ventricle which exhibited the greatest excursion could be placed just above the slit. The $x$-ray tube was placed above the dog, 34 inches from the lead screen. Between the dog and the lead screen a stationary cassette (fig. 2,1 ) was inserted which held a film. On this the familiar $\mathrm{x}$-ray photograph of the heart was taken, as well as the position of the time recorder. This lever (acting as a pointer) indicated which portion of the heart's border was later photographed on the moving film, the lever and that portion lying over the slit

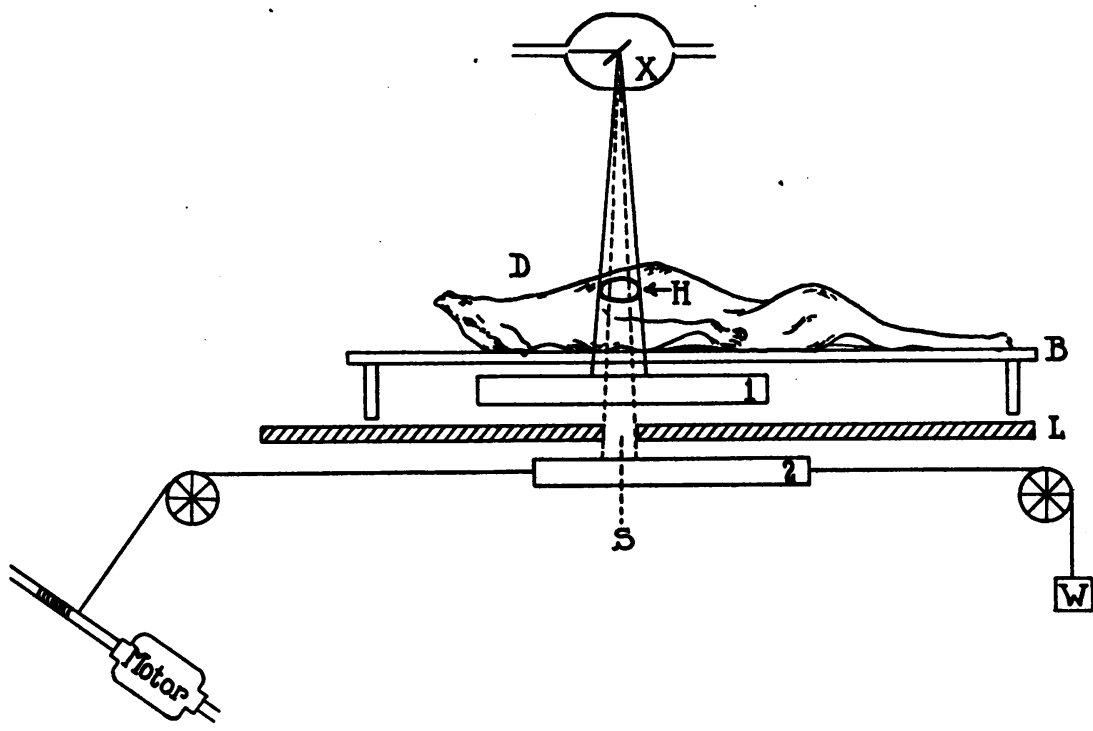

Fig. 2. Schematic Drawing of the X-Ray Apparatus Illustrating the METHOD OF EXPOSING THE X-RAY FIMMS

$X, x$-ray tube; $D, \operatorname{dog}$ lying on dog board; $B$, dog board; $L$, lead screen; $S$, $0.5 \mathrm{~cm}$. slit in lead screen; 1 , cassette carrying control x-ray film; 2 , moving $x$-ray film drawn past slit by motor; $W$, counter-weight.

Below the lead screen there was placed a second cassette (fig. 2, 2) containing a film which was drawn past the slit on a track by a motor. Since the films are wider than a dog's chest, respiratory movements, like those of the heart's borders, could be and were recorded without additional mechanical means. During their preliminary training the motion of points at several levels of a dog's heart were photographed, so that the level which gave the greatest excursion might be selected for further study.

We were able occasionally to measure curves obtained at two levels, at the 6th interspace, in $\operatorname{dog} 265$ (table 1, fig. 3) as well as at the level of the 6th rib. 
Effect of digitalis on cardiac output, cardiac

\begin{tabular}{|c|c|c|c|c|c|c|c|c|c|c|c|c|c|c|}
\hline \multirow[b]{2}{*}{ 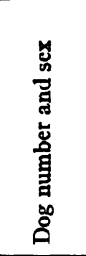 } & \multirow[b]{2}{*}{$\stackrel{\Perp}{\Xi ّ}$} & \multirow[b]{2}{*}{ 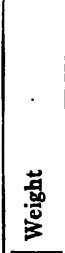 } & \multicolumn{2}{|c|}{$\mathrm{O}_{2}$ content } & \multirow{2}{*}{ 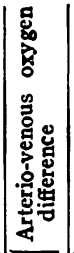 } & \multirow{2}{*}{ 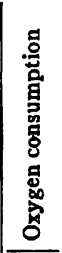 } & \multirow{2}{*}{ 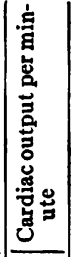 } & \multirow{2}{*}{ 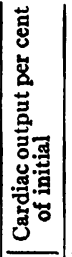 } & \multirow[b]{2}{*}{ 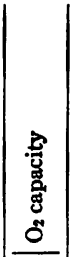 } & \multicolumn{2}{|c|}{$\begin{array}{l}\mathrm{O}_{2} \text { satu- } \\
\text { ration } \boldsymbol{f}\end{array}$} & \multicolumn{3}{|c|}{ Analysis of stationary films } \\
\hline & & & 丞 & 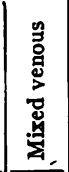 & & & & & & 胥 & 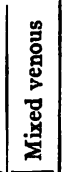 & 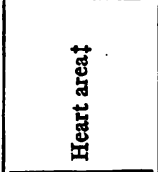 & 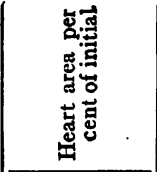 & 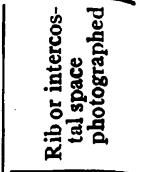 \\
\hline $\begin{array}{l}257 \\
\text { Male }\end{array}$ & \begin{tabular}{|c|c|}
\multicolumn{2}{c}{1928} \\
January 31 \\
\\
\\
February & 1 \\
February & 2 \\
February & 4 \\
February & 10
\end{tabular} & $\begin{array}{l}k g m . \\
12.4 \\
11.7 \\
11.7 \\
11.5 \\
12.0\end{array}$ & $\begin{array}{c}\text { ool- } \\
\text { wmes } \\
\text { per } \\
\text { cent } \\
14.97 \\
\\
14.72 \\
14.87 \\
13.51 \\
12.57 \\
11.50\end{array}$ & \begin{tabular}{|c|} 
vol- \\
iumes \\
per \\
cent \\
12.12
\end{tabular} & 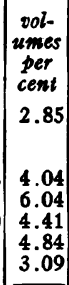 & $\begin{array}{c}c c . \\
\text { per } \\
\text { min- } \\
\text { ule } \\
109 \\
\\
95 \\
108 \\
104 \\
107 \\
111\end{array}$ & $\begin{array}{c}c c . \\
3,820 \\
\\
2,351 \\
1,790 \\
2,359 \\
2,210 \\
3,592\end{array}$ & \begin{tabular}{|c|} 
per \\
cent \\
\\
100.0 \\
\\
61.5 \\
46.8 \\
61.7 \\
57.8 \\
94.0 \\
\end{tabular} & \begin{tabular}{|c|} 
vol- \\
wmes \\
per \\
cent \\
15.93 \\
\\
16.49 \\
16.33 \\
15.42 \\
13.44 \\
12.05
\end{tabular} & $\begin{array}{l}88.1 \\
89.9 \\
84.9 \\
92.0 \\
93.8\end{array}$ & $\begin{array}{l}64.3 \\
53.5 \\
62.0 \\
56.8 \\
69.0\end{array}$ & $\begin{array}{l}\text { sq. } \mathrm{cm} . \\
\\
52.7 \\
\\
47.7 \\
43.8 \\
48.2 \\
47.7 \\
51.5\end{array}$ & $\begin{array}{c}\text { per cent } \\
\\
100.0 \\
\\
90.5 \\
83.1 \\
91.4 \\
90.5 \\
97.7\end{array}$ & $\begin{array}{l}\text { 7th rib } \\
7 \text { th rib } \\
7 \text { th rib } \\
7 \text { th rib } \\
7 \text { th rib } \\
7 \text { th rib }\end{array}$ \\
\hline $\begin{array}{c}258 \\
\text { Female }\end{array}$ & $\begin{array}{ll}\text { February } 6 \\
\\
\\
\text { February } 7 \\
\text { February } 8 \\
\text { February } .9\end{array}$ & $\begin{array}{l}14.8 \\
15.5 \\
15.5\end{array}$ & $\begin{array}{l}18.31 \\
18.56 \\
16.47 \\
15.42\end{array}$ & $\begin{array}{l}13.09 \\
15.65 \\
13.90 \\
12.87\end{array}$ & \begin{tabular}{|l|}
2.96 \\
\\
5.22 \\
2.91 \\
2.57 \\
2.55 \\
\end{tabular} & \begin{tabular}{|l|}
127 \\
130 \\
135 \\
138 \\
\end{tabular} & $\begin{array}{l}4,696 \\
\\
2,433 \\
4,467 \\
5,252 \\
5,372\end{array}$ & $\begin{array}{r}51.8 \\
95.1 \\
111.8 \\
114.4 \\
\end{array}$ & $\begin{array}{l}19.34 \\
19.42 \\
17.25 \\
16.15\end{array}$ & $\begin{array}{l}93.7 \\
94.6 \\
94.3 \\
94.2\end{array}$ & $\begin{array}{l}66.9 \\
80.1 \\
79.4 \\
79.1\end{array}$ & $\begin{array}{l}69.1 \\
56.7 \\
60.0 \\
63.0\end{array}$ & $\begin{array}{l}100.0 \\
82.0 \\
87.0 \\
91.0\end{array}$ & $\begin{array}{l}\text { 8th rib } \\
\text { 8th rib } \\
\text { 8th rib } \\
\text { 8th rib } \\
\end{array}$ \\
\hline $\begin{array}{c}259 \\
\text { Male }\end{array}$ & $\begin{array}{l}\text { February } 15 \\
\text { February } 17 \\
\text { February } 21\end{array}$ & $\begin{array}{l}17.5 \\
17.5 \\
17.7 \\
\end{array}$ & $\begin{array}{l}21.93 \\
21.00 \\
19.32 \\
17.79\end{array}$ & $\begin{array}{l}17.60 \\
16.08 \\
15.90 \\
16.16 \\
\end{array}$ & \begin{tabular}{|l|}
2.15 \\
\\
4.33 \\
4.92 \\
3.42 \\
1.63 \\
\end{tabular} & \begin{tabular}{|l|}
114 \\
116 \\
125 \\
119 \\
\end{tabular} & $\begin{array}{l}5,256 \\
\\
2,633 \\
2,357 \\
3,655 \\
7,300 \\
\end{array}$ & $\begin{array}{r}50.0 \\
44.8 \\
69.5 \\
140.0 \\
\end{array}$ & $\begin{array}{l}23.42 \\
22.05 \\
19.98 \\
19.22 \\
\end{array}$ & $\begin{array}{l}92.8 \\
94.3 \\
95.7 \\
91.6\end{array}$ & $\begin{array}{l}74.7 \\
72.5 \\
79.1 \\
83.6\end{array}$ & $\begin{array}{l}70.8 \\
64.5 \\
72.6 \\
78.0 \\
\end{array}$ & $\begin{array}{l}100.0 \\
\\
89.8 \\
81.1 \\
92.1 \\
98.8 \\
\end{array}$ & $\begin{array}{l}\text { 6th rib } \\
\text { 6th rib } \\
\text { 6th rib } \\
\text { 6th rib } \\
\text { 6th rib } \\
\end{array}$ \\
\hline $\begin{array}{l}261 \\
\text { Male }\end{array}$ & February 23 & 12.8 & 20.81 & 7.30 & 4.73 & 122 & 2,580 & 100.0 & 22.39 & 92.1 & 32.3 & 37.1 & 100.0 & $\begin{array}{l}\text { 6th inter- } \\
\text { space } \\
\text { 6th inter- } \\
\text { space } \\
\end{array}$ \\
\hline $\begin{array}{l}263 \\
\text { Male }\end{array}$ & $\begin{array}{l}\text { February } 29 \\
\text { March } 2 \\
\text { March } 8\end{array}$ & $\begin{array}{l}10.3 \\
10.7 \\
10.8\end{array}$ & $\begin{array}{l}23.88 \\
21.55 \\
18.55 \\
17.72\end{array}$ & $\begin{array}{l}14.36 \\
15.96 \\
14.84 \\
14.02\end{array}$ & $\begin{array}{l}9.52 \\
5.59 \\
3.71 \\
3.70\end{array}$ & $\begin{array}{l}86 \\
95 \\
96 \\
97 \\
\end{array}$ & $\begin{array}{r}1,707 \\
902 \\
1,698 \\
2,588 \\
2,622\end{array}$ & $\begin{array}{r}52.8 \\
99.6 \\
151.5 \\
153.5\end{array}$ & $\begin{array}{l}25.50 \\
21.93 \\
19.16 \\
18.26\end{array}$ & $\begin{array}{l}92.9 \\
97.7 \\
95.7 \\
95.9\end{array}$ & $\begin{array}{l}55.9 \\
72.3 \\
80.3 \\
76.2\end{array}$ & $\begin{array}{l}51.1 \\
50.4 \\
54.4 \\
57.4\end{array}$ & $\begin{array}{r}100.0 \\
\\
90.9 \\
89.7 \\
96.8 \\
100.2 \\
\end{array}$ & $\begin{array}{l}7 \text { th rib } \\
\text { 7th rib } \\
7 \text { th rib } \\
\text { 7th rib } \\
7 \text { th rib } \\
\end{array}$ \\
\hline $\begin{array}{l}265 \\
\text { Male }\end{array}$ & $\begin{array}{l}\text { March } 6 \\
\text { March } 10\end{array}$ & $\begin{array}{l}9.4 \\
9.4\end{array}$ & $\begin{array}{l}16.03 \\
14.46 \\
14.12\end{array}$ & $\begin{array}{r}9.26 \\
10.89 \\
11.75\end{array}$ & $\begin{array}{l}6.77 \\
3.57 \\
2.27\end{array}$ & $\begin{array}{l}98 \\
99 \\
96\end{array}$ & $\begin{array}{l}1,447 \\
2,773 \\
4,190\end{array} \mid$ & $\begin{array}{l}33.6 \\
64.4 \\
95.0\end{array}$ & $\begin{array}{l}17.40 \\
15.38 \\
15.13\end{array}$ & $\begin{array}{l}91.0 \\
92.7 \\
92.0\end{array}$ & $\begin{array}{l}52.6 \\
70.1 \\
77.0\end{array}$ & $\begin{array}{rr}34.8 & 35.4 \\
& 37.7 \\
40.1 & 40.2\end{array}$ & \begin{tabular}{|rr}
6 th I.S. 6th rib \\
100.0 & 100.0 \\
& \\
87.5 & 88.3 \\
100.7 & 100.0
\end{tabular} & $\begin{array}{l}\text { 6th I.S. and } \\
\text { 6th rib } \\
\text { 6th I.S. and } \\
\text { 6th rib } \\
\text { 6th rib } \\
\text { 6th I.S. and } \\
\text { 6th rib } \\
\end{array}$ \\
\hline $\begin{array}{l}266 \\
\text { Male }\end{array}$ & $\begin{array}{ll}\text { March } & 7 \\
\text { March } & 8 \\
\text { March } & 9\end{array}$ & $\begin{array}{l}13.6 \\
14.0 \\
14.0\end{array}$ & $\begin{array}{l}14.89 \\
14.99 \\
14.40\end{array}$ & $\mid \begin{array}{l}11.50 \\
12.09 \\
11.62\end{array}$ & \begin{tabular}{|l|}
3.39 \\
2.90 \\
2.78
\end{tabular} & $\begin{array}{l}127 \\
138 \\
141\end{array}$ & $\left|\begin{array}{l}3,775 \\
4,800 \\
5,035\end{array}\right|$ & $\begin{array}{l}60.0 \\
76.2 \\
80.5\end{array}$ & $\left|\begin{array}{l}16.09 \\
15.74 \\
15.52\end{array}\right|$ & $\begin{array}{l}91.3 \\
94.0 \\
91.5\end{array} \mid$ & $\mid \begin{array}{l}69.2 \\
76.2 \\
74.2\end{array}$ & $\begin{array}{l}51.2 \\
53.6 \\
56.6\end{array}$ & $\begin{array}{l}87.8 \\
91.9 \\
97.1\end{array}$ & $\begin{array}{l}\text { 6th rib } \\
\text { 6th rib } \\
\text { 6th rib }\end{array}$ \\
\hline
\end{tabular}

$* \mathrm{~V}=$ vomited.
$\dagger$ Before calculating the oxygen saturations 0.2 and 0.1 volumes per cent (the amounts of oxygen in physical solution) were subtracted from the arterial and mixed venous contents respectively.

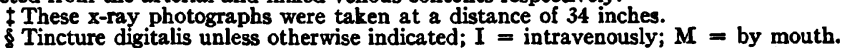


LE 1

size and ventricular excursions in normal dogs

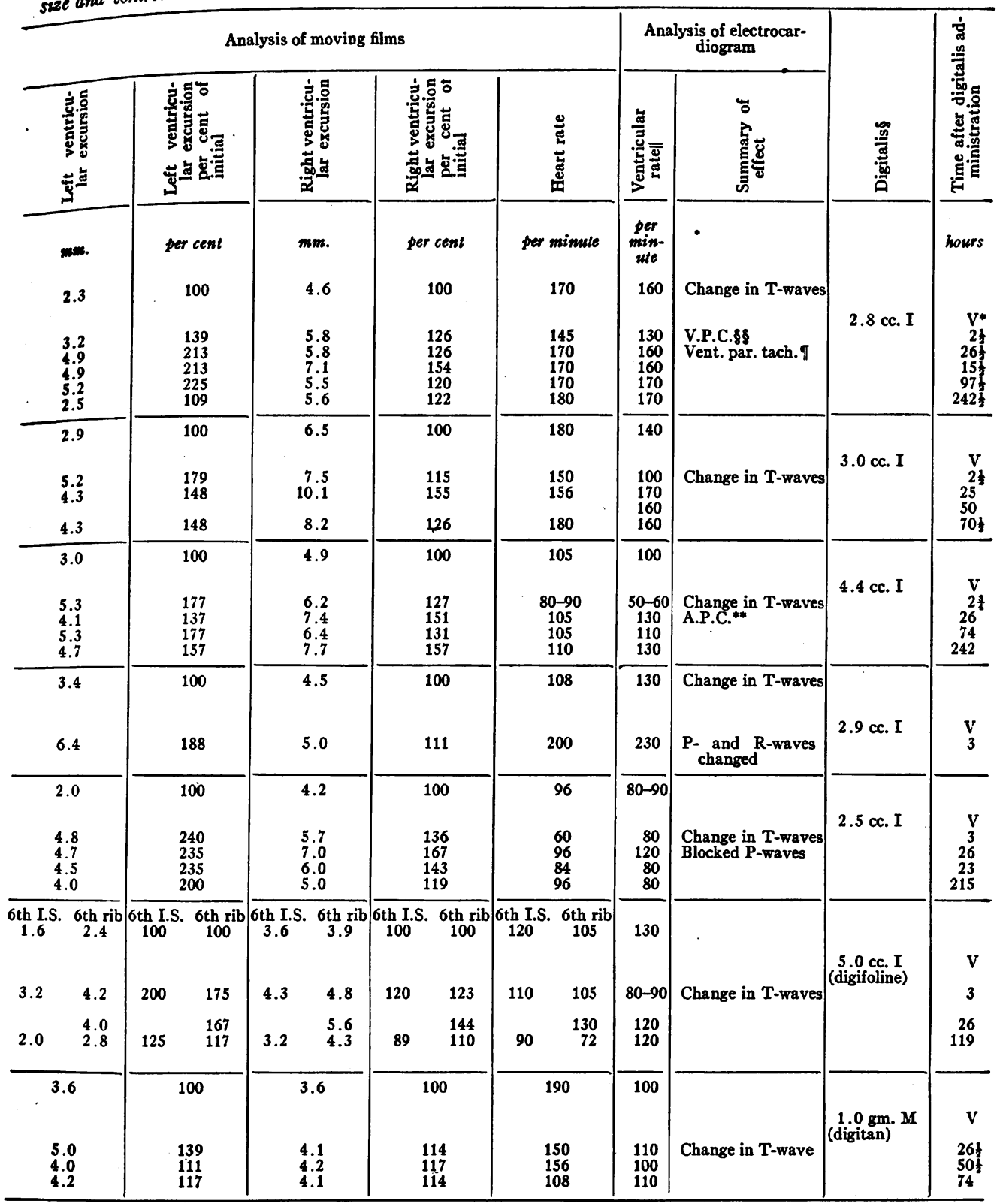

The rhythm was in all cases normal.

8 V.P.C. = ventricular premature contractions.

IVent. par. tach. $=$ ventricular paroxysmal tachycardia.

A.P.C. = auricular premature contractions. 


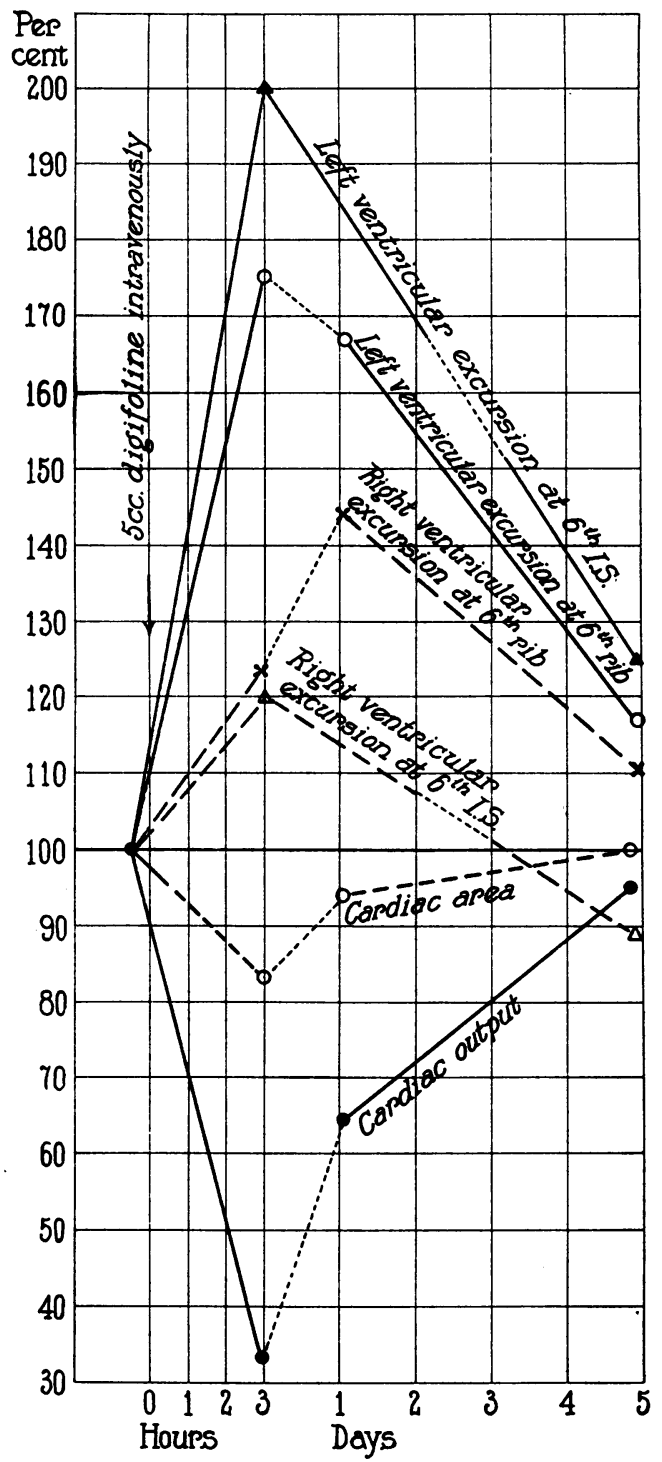

Fig. 3. Showing the Effect of Giving Digitalis on Cardiac Output, Cardiac Size and Excursions of the Right and Left Ventricles in Dog 265

Photographs were made at the 6th interspace as well as at the level of the 6th rib. As the effect of digitalis wore off cardiac output, cardiac size and extent of ventricular excursions returned simultaneously toward normal. 
At both levels there was an increase in contraction after digitalis was given, and a return toward normal as the digitalis effect wore off. In general the left and right ventricular excursions at the level of the 6th rib were slightly greater than at the level of the 6th interspace. That the extent of contraction differs at various points on the heart silhouette has become known through cinematographs published by Eyster and Meek (1920).

Usually when once the location of greatest excursion was discovered this level was marked permanently on the dog's chest in order that subsequent observations might always be made of this point. The anti-cathode of the $\mathrm{x}$-ray tube, this mark on the dog's chest and the slit were always in the same vertical line. Care was also taken to see to it that the dogs were in true antero-posterior position.

That the results obtained by the use of this method are valid is demonstrated by measurements which were taken in one dog over a period of two weeks (table 2).

TABLE 2

Measurements of curves of a normal dog (dog 257) at an interval of two weeks

\begin{tabular}{|c|c|c|c|c|c|c|c|c|}
\hline \multirow{3}{*}{ Date } & \multirow{3}{*}{$\begin{array}{l}\text { Level } \\
\text { photo- } \\
\text { gtaphed }\end{array}$} & \multicolumn{4}{|c|}{ Analysis of moving film } & \multirow{3}{*}{$\begin{array}{l}\text { Heart } \\
\text { rate }\end{array}$} & \multicolumn{2}{|c|}{$\begin{array}{l}\text { Analysis of sta- } \\
\text { tionary film }\end{array}$} \\
\hline & & \multicolumn{2}{|c|}{$\begin{array}{l}\text { Left ventricular } \\
\text { excursion }\end{array}$} & \multicolumn{2}{|c|}{$\begin{array}{c}\text { Right ventricular } \\
\text { excursion }\end{array}$} & & \multirow{2}{*}{$\begin{array}{c}\text { Area of } \\
\text { heart }\end{array}$} & \multirow{2}{*}{$\begin{array}{c}\text { Area of } \\
\text { heart } \\
\text { per cent } \\
\text { of initial }\end{array}$} \\
\hline & & Height & $\left|\begin{array}{l}\text { Per cent } \\
\text { of initial }\end{array}\right|$ & Height & $\left|\begin{array}{l}\text { Per cent } \\
\text { of initial }\end{array}\right|$ & & & \\
\hline & & $m m$ & per cenl & $m m$ & percent & $\begin{array}{c}\text { per } \\
\text { minu.e }\end{array}$ & $s q . \mathrm{cm}$ & percent \\
\hline January 17,1928 . & 6 th rib & 3.0 & 100 & 3.8 & 100 & 140 & 53.6 & 100.0 \\
\hline January $18,1928$. & 6th rib & 2.8 & 93 & 3.7 & 97 & 165 & 54.6 & 101.8 \\
\hline January 28,1928 . & 6 th rib & 2.9 & 97 & 3.9 & 103 & 132 & 54.7 & 102.0 \\
\hline January 31,1928 . & 6th rib & 2.9 & 97 & 3.8 & 100 & 170 & 55.2 & 103.0 \\
\hline
\end{tabular}

On January 17, 1928, the left ventricular excursion at the level of the 6th rib measured $3.0 \mathrm{~mm}$.; the next day, $2.8 \mathrm{~mm}$; 10 days later (January 28), $2.9 \mathrm{~mm}$.; and 3 days later still (January 31 ), $2.9 \mathrm{~mm}$. On corresponding days right ventricular excursions measured $3.8,3.7,3.9$, and $3.8 \mathrm{~mm}$. respectively. Constant comparable curves are obviously obtainable over a longer period of time than the duration of these experiments. Inspection of the stationary films taken at the same time showed that identical points of the left and right ventricular borders had been photographed on the moving films. The heart meanwhile had not changed in size. The variation of 3 per cent which was found is within the error of the method.

The stationary film was exposed first during inspiration and then removed. Without changing the dog's position the moving film ${ }^{1}$ was next exposed during

${ }^{1}$ Eastman duplitized films were used in a reenforced French cassette. 

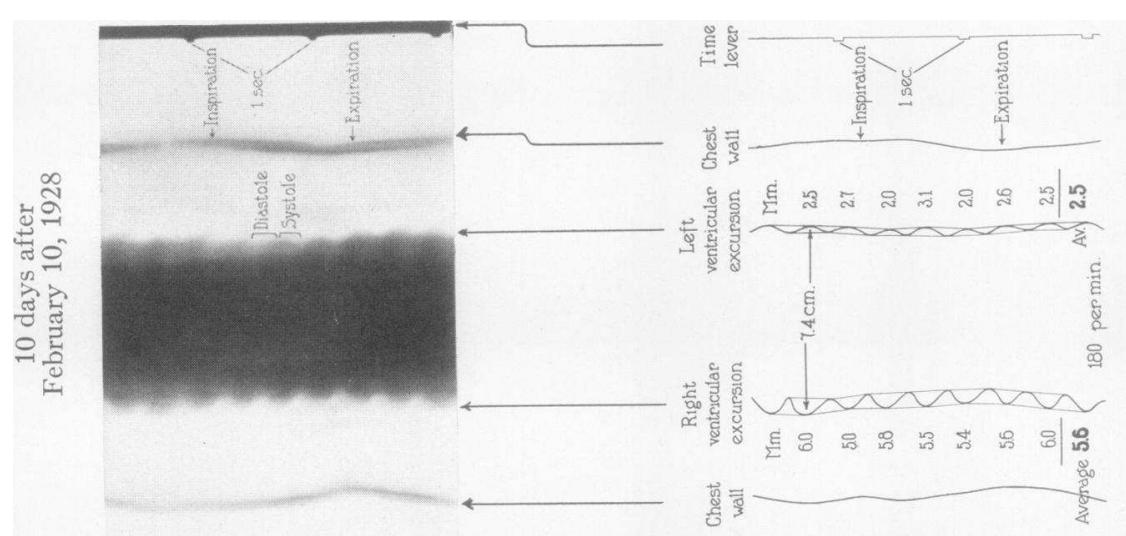

్ㅗ

$\stackrel{5}{00}$

㝳

范
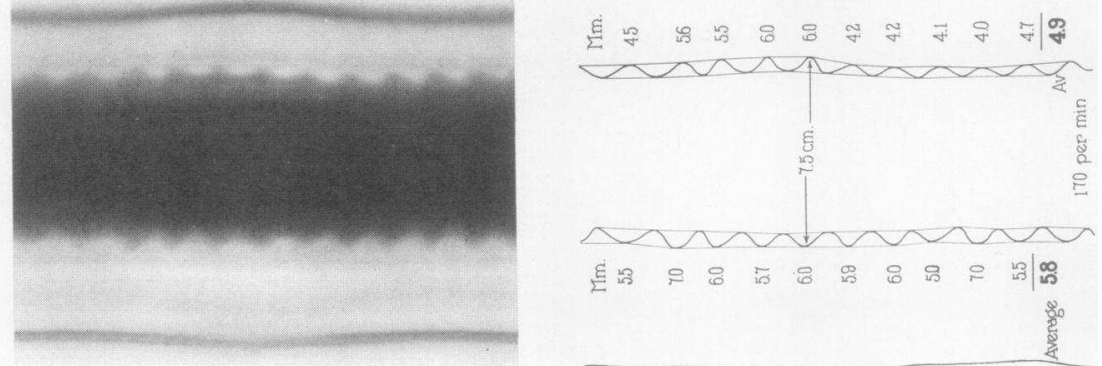

고

帘 댕 岳要

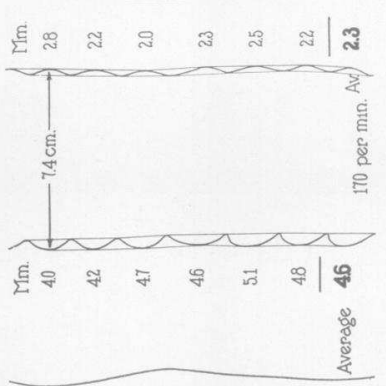


normal quiet breathing. The cardiac records which are obtained by this method are similar to sine curves, the troughs and the crests representing systolic and diastolic positions (fig. 4). The curves were traced on thin paper (fig. 4) and tangents were drawn to the troughs and crests. The distance between these tangents we took to represent the extent of ventricular contraction. All the waves in a single respiratory cycle were accordingly measured and the average figure used as the basis of comparison. In the photographs made day after day only those were studied in which it was established that identical levels of the heart's margins had been photographed. In most of the exposures the motions of the right as well as of the left ventricular excursions were photographed sharply enough to be measured.

To estimate the effect of digitalis on the size of the heart, that is to say its dimensions in the frontal plane, its area as seen in the stationary films was measured (Stewart, 1927). The diastolic size of the heart we took to represent what we choose to regard as the evidence of its tone; any change in diastolic size, we regarded as a change in tone. In those stationary photographs in which both the systolic as well as the diastolic position of the heart could be identified, the diastolic area was the one measured. No corrections have been made in the measurements of the moving films in order to obtain values comparable to those taken at a distance of two meters. We have neglected to do this because the conclusions which we draw are independent of the magnification caused by the divergence of the $\mathrm{x}$-rays. There is of course an error due to the decrease in size of the heart after giving digitalis, but the greater the decrease the less is the error due to magnification of the excursion. Should this error be corrected, the magnitude of the changes which we found would be exaggerated. We have therefore as in our earlier study, neglected it.

\section{PLAN OF OBSERVATIONS}

Observations were made before and at varying intervals after the administration of digitalis, the first usually after 2 to 3 hours, then 24 hours later and again at longer intervals up to 5 to 10 days. The observations were always made in the following order: The $\mathrm{x}$-ray photographs (stationary and moving) were made first, then followed estimations of the cardiac output; and finally electrocardiograms were taken in the standard manner. Tincture of digitalis ${ }^{2}$ (Upsher Smith) was injected intravenously. We injected in one dose 25 to 30 per cent of the calculated lethal dose. We chose this amount because Robinson and Wilson (1918) found the therapeutic dose of digitalis for cats to be 30 per cent of the calculated lethal dose and because

2 The cat unit of the preparation was 0.65 cc. 
Cohn (Cohn) found that the dose for cats must be multiplied by the factor 1.16 to arrive at a comparable quantity for dogs. We have accordingly injected this amount. To several dogs we administered digifoline (Ciba) intravenously for the sake of comparison with the experiments of Harrison and Leonard (1926). Of this preparation we injected 0.5 cc. per kilogram of body weight (Harrison and Leonard (1926), Pardee (1925)). To one dog we gave digitan (Merck) 1.0 gram by mouth. The same phenomena resulted irrespective of the preparation that was administered.

\section{OBSERVATIONS}

In 7 dogs we have complete data of the effect of giving digitalis on cardiac output, cardiac size and ventricular contraction (excursions).

The effect of digitalis on cardiac output. In dog 257 the cardiac output was $3820 \mathrm{cc}$. per minute (table 1, fig. 5). Two and one-half hours after tincture of digitalis $2.8 \mathrm{cc}$. had been given intravenously the output fell to $2351 \mathrm{cc}$. per minute; there occurred, that is to say, a decrease to 61.2 per cent of the initial output. Later, at $26 \frac{1}{2}$ hours, the output fell still further to $1790 \mathrm{cc}$., equal to 46.8 per cent only of the output at the beginning. On the second day there was a change. The output increased to $2359 \mathrm{cc}$. and in 10 days returned to 3592 cc., that is to say, to 94 per cent of the initial value. In this dog then there was after the administration of digitalis a decrease in cardiac output within $2 \frac{1}{2}$ hours which reached a maximum 24 hours later. The return to normal, though not complete, took place at the end of 10 days.

The results were similar in the other 6 dogs (table 1, figs. 3 and 6), with this exception, namely that in 3 dogs (dog 258 (fig. 6), dog 259 and $\operatorname{dog} 263$ ) the output, following the initial decrease actually became greater than it had been at first. This observation will be discussed later at greater length. In general, though, the output decreased uniformly $2 \frac{1}{2}$ to 3 hours after the administration of digitalis, but the maximum was usually delayed until 24 hours later. It varied between 34 and 62 per cent of the initial value (table 1). Later the cardiac output returned toward normal ( $\operatorname{dog} 261$, dog 265 (fig. 3) and $\operatorname{dog} 266$ ) or exceeded this value (dog 258 (fig. 6), dog 259 and $\operatorname{dog} 263)$. The changes in output occurred irrespective of changes 


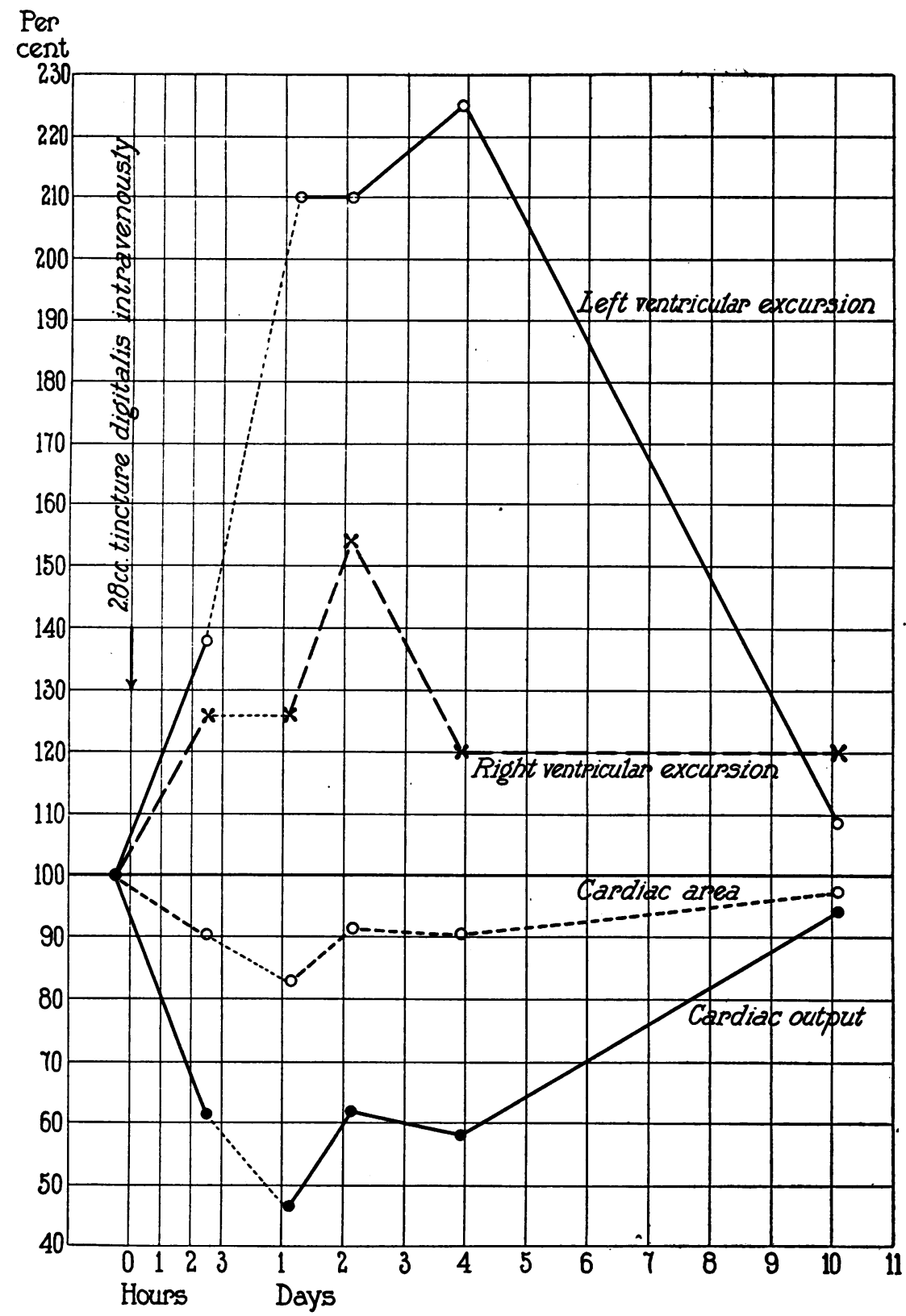

Fig. 5. Showing the Effect of Giving Digitalis on. Cardiac Output, Size

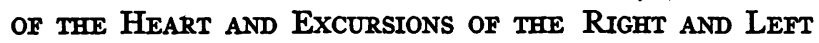
VENTRICLES IN DOG 257

Attention is called to the fact that in this dog the cardiac output, area of the heart and ventricular excursions returned toward normal (100 per cent) simultaneously. 
in heart rate (recorded electrocardiographically) though this was found usually to have decreased 2 to 3 hours after administration. Later the rate returned to what it was at the outset of the experiment.

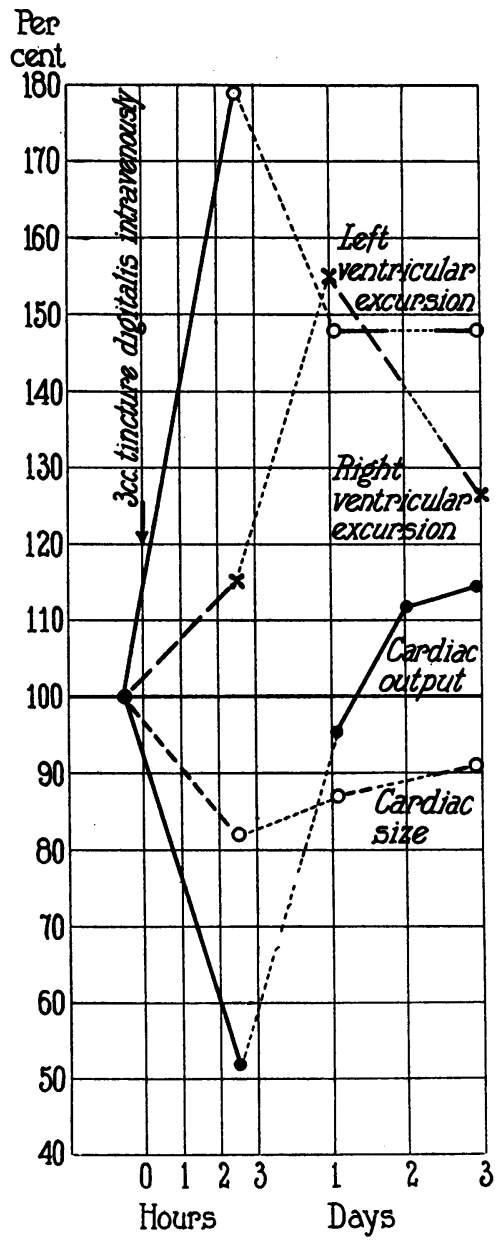

Fig. 6. Showing the Effect of Giving Digitalis on Cardiac Output, Cardiac Size and Excursions of the Right and Left Ventricles in Dog 258

In this instance, after the preliminary decrease, the cardiac output increased and overshot the initial measurement even though the heart was smaller than it was in the beginning. This result is attributed to the fact that the height of the ventricular excursions continued greater than it was in the initial measurements. 
The effect on output depended on two factors, tone and contraction. These were therefore analyzed separately.

1. The Effect of digitalis on the size of the heart (tone). In dog 257 the initial heart area was $52.7 \mathrm{sq} . \mathrm{cm}$. It decreased to $47.7 \mathrm{sq} . \mathrm{cm}$. $2 \frac{1}{2}$ hours after digitalis was given (table 1, figs. 5 and 7 ), and 24 hours later still farther to $43.8 \mathrm{sq}$. $\mathrm{cm}$. Following this fall there was a gradual return toward normal, so that at the end of 10 days the area measured $51.5 \mathrm{sq} . \mathrm{cm}$. There was then a maximum fall to 83 per cent of the initial size in $26 \frac{1}{2}$ hours, followed by a return toward normal as the effect of digitalis wore off.

The results in the other 6 dogs corresponded to this one. The maximum decreases varied between 72 and 90 per cent of the initial measurement (table 1, figs. 3 and 6), the maximum being attained sometimes 2 to 3 hours and at other times not until 24 hours after the drug was given. As the effect of the drug wore off the dimensions of the cardiac area returned toward normal.

2. Effect of digitalis on contraction. In $\operatorname{dog} 257$ the excursion of the margin of the left ventricle at the level of the 6th rib measured $2.3 \mathrm{~mm}$. Within $2 \frac{1}{2}$ hours after tincture digitalis $2.8 \mathrm{cc}$. was administered the excursion increased to $3.2 \mathrm{~mm}$. and 24 hours later still farther to $4.9 \mathrm{~mm}$. The excursions were still greater $(5.2 \mathrm{~mm}$.) 4 days later than at the beginning, but at the end of 10 days they returned to normal $(2.5 \mathrm{~mm}$.) (table 1, figs. 4 and 5). The excursion of the right ventricle likewise increased, in this case.from the initial value, $4.6 \mathrm{~mm}$. to a maximum of $7.1 \mathrm{~mm}$. The return toward normal occurred in 10 days (table 1, figs. 4 and 5). The extent of contraction was therefore more than doubled in this dog.

In the other 6 dogs the results were identical; the ventricular excursions were always increased after digitalis was given (table 1, figs. 3 and 6). It is important to point out that the effect on contraction and on the tone of the muscle was not always parallel. The difference between the two became apparent when the effect of digitalis wore off. The effect on contraction often persisted longer than that on tone. Which was to be the predominating effect was not predictable.

Effect of digitalis on the cardiac mechanism and on the electrocardiograms. The effect on the electrocardiograms observed most con- 

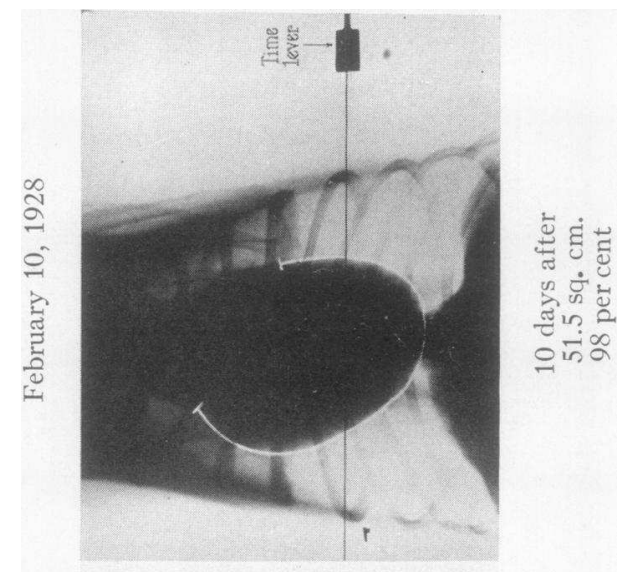

$\stackrel{\text { g }}{\mathrm{E}}$

กิ

○ั

당 吾

4

赵

藏

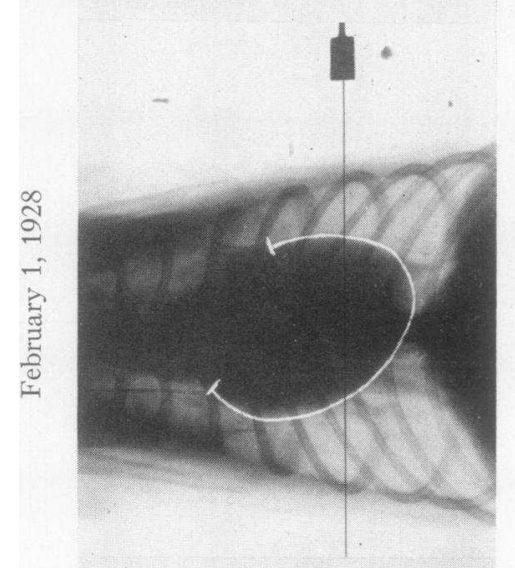

舅声

幽

언

जै.

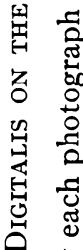

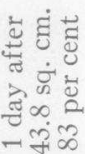

它

ज्ञ

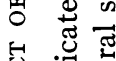

苾:

政

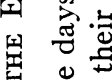

$\rightarrow$ 岁

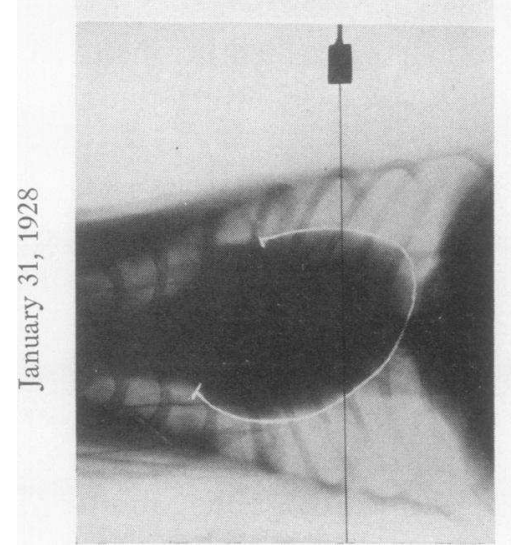

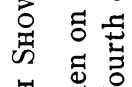

黛志芯

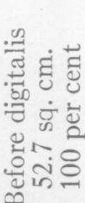

is

究

案 究

잉

㱏苔

$\therefore$ त氧

昰

률 
stantly was change in the form of the $T$-waves (table 1 ). If the waves were negative in the beginning their size might show slight changes; in other cases waves became positive; and in other still, positive ones became negative. These changes persisted 24 to 48 hours, but the initial form was always regained at the end of 4 days. There was no change in conduction time. The ventricular rate was usually slower 2 to 3 hours after giving digitalis, but returned to the first rate 24 hours afterward (table 1). Dog 261 is an exception. Sinus tachycardia, 230 per minute, developed after digitalis was given. The dog died within 18 hours. Runs of ventricular tachycardia (dog 257), auricular premature contractions (dog 259) and blocked auricular waves (dog 263) were each encountered once.

Effect of digitalis on metabolism. The oxygen consumption of each dog remained practically constant (table 1), nor did significant changes occur following the administration of digitalis. The small fluctuations which were found from day to day were obviously unimportant.

\section{ADDITIONAL OBSERVATIONS}

We are able to make report of the action of digitalis in 6 other dogs which were studied in the same way as were those already described. The experiments differ only in that we have no photographic curves showing ventricular contraction. Changes in cardiac output and cardiac area were however studied (table 3). The usual stationary $\mathrm{x}$-ray photographs of the heart were made. In these as in the other dogs the effect of injecting digitalis was to decrease the cardiac output, the maximum reduction being attained in 2 to 24 hours. There was then a return toward normal or even an over-shooting of it. At the same time the size of the heart was likewise decreased. The ventricular rate was as in the others always slowed 2 to 3 hours afterward, except in one $\operatorname{dog}(\operatorname{dog} 254)$ in which ventricular paroxysmal tachycardia occurred. Changes in the T-wave were constantly observed. There were no changes in conduction time. 


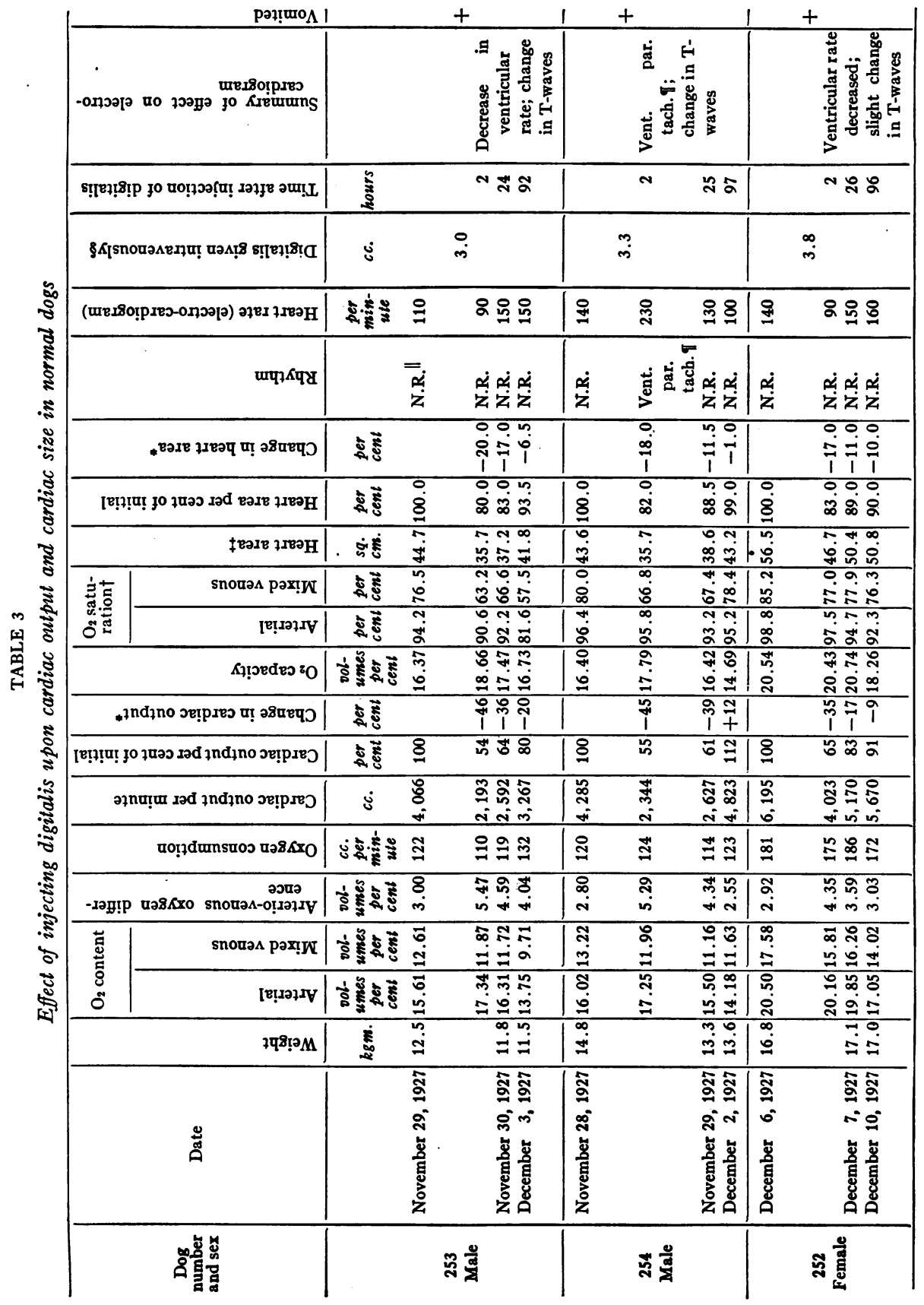




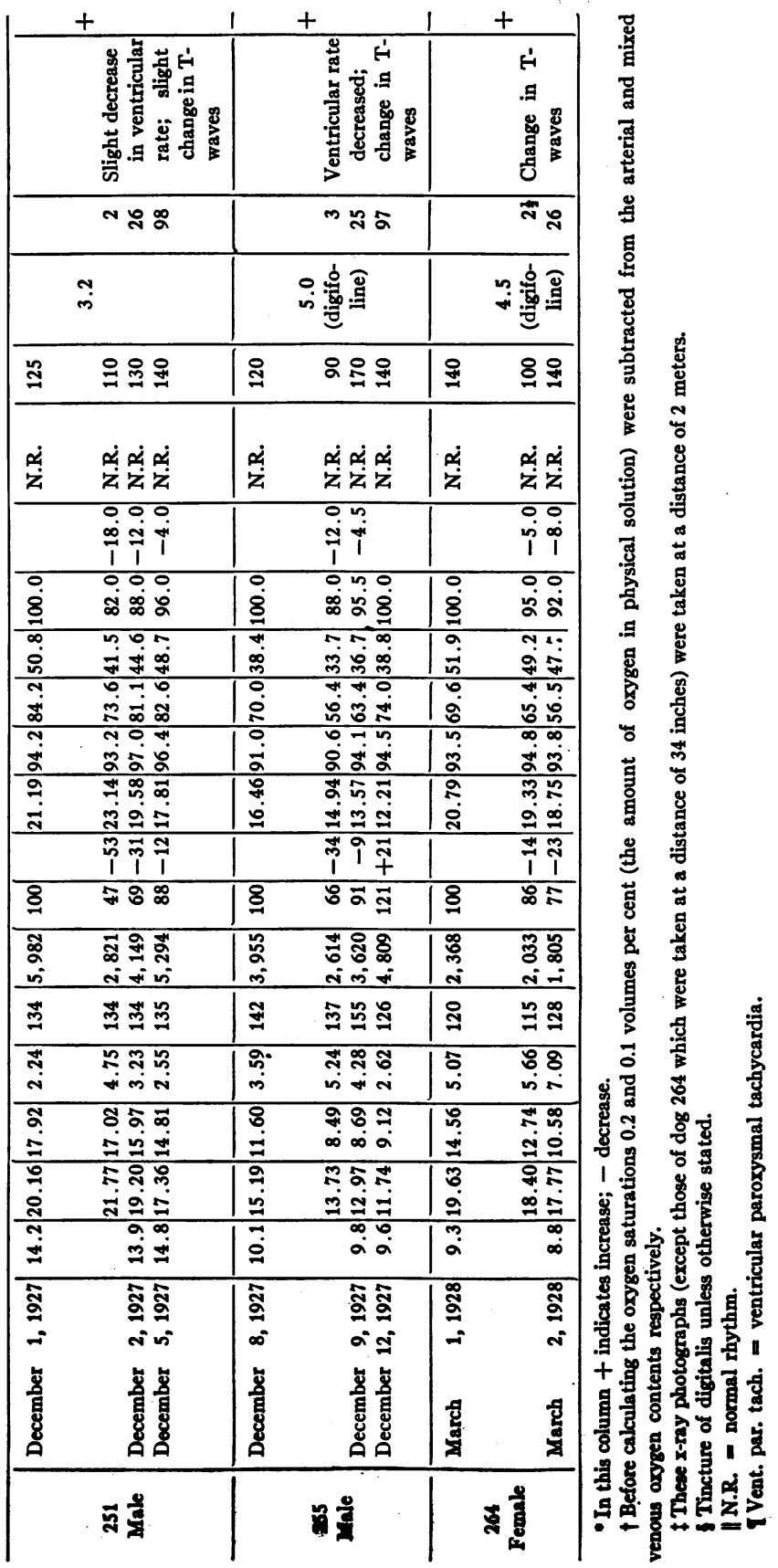

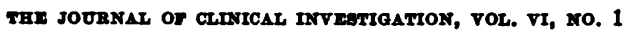




\section{SUMMARY}

Following the administration of digitalis to normal dogs in socalled therapeutic amounts the following effects were observed: (1) the form of the T-wave in the electrocardiogram changed; (2) the cardiac output decreased; (3) the size of the heart decreased; (4) the height of ventricular excursions increased. When digitalis was excreted all these measurements returned toward normal.

\section{DISCUSSION}

We have demonstrated then that following the administration of digitalis to normal dogs the cardiac output and the cardiac size decreased; but the extent of ventricular contraction on the other hand increased. In what way are these observations to be connected in analyzing the effect of digitalis on cardiac output? In our early experiments (Cohn and Stewart, 1928a) the six to which reference has just been made and in which cardiac output and cardiac size alone were correlated, there was close agreement between the two; when the cardiac size decreased the cardiac output decreased,-as we thought, necessarily. But that the influence of digitalis on the two functions was distinct and separable became apparent when the effect of digitalis began to wear off. When the size of the heart began to increase, the output sometimes increased more than it should have done were size the only factor involved (dogs 254 and 255, table 3). Why this was so was difficult at first to explain, but the reason became evident as we thought, when we began to take into account the effect of the drug on contraction... There was ample reason to anticipate a striking effect on this function based on evidence gained by many other observers from experiments on animals that had been operated on. What the effect is in intact animals to which no anesthetic had been given was however unknown. ...The method of the moving film employed in this study permitted an answer to this question; ventricular contraction increases in the intact as it does in the animal which has been operated upon.

There are in fact two opposed actions of digitalis; there is an effect on the size of the heart, which we Interpret-as being an effect on tone, in this case an increase in tone of the heart muscle, from 
which there results naturally a decrease in cardiac output. The smaller pump expels a smaller volume. There is also an effect on contraction indicated by an increase in the height of the ventricular excursions. A result of this action is a tendency more completely to empty the heart at each systole and so to increase the cardiac output. The net effect of these two actions, the one tending to decrease and the other to increase the output, varied so that the results in all stages but especially the later ones are not always predictable. During the first day, in all dogs, the effect on tone predominated over the effect on contraction so that the dimensions of the ventricular cavities diminished and the output in consequence was decreased in spite of the fact that the extent of the ventricular excursions sometimes doubled (figs. 3, 5 and 6). Later, when the effect on tone began to diminish, the output rose occasionally above the initial value even though the size of the heart continued to be smaller than it. was in the beginning. We attribute this result to persistence of the effect on contraction ( $\operatorname{dog} 258$ (fig. 6), dog 259 and dog 263). In this case the heart was larger than a minimum critical value. It appears clear to us that when the size of the heart becomes smaller than the critical value, the possibility of increased output disappears, even though marked increase in the height of the ventricular excursions takes place. We have been puzzled to know the source of the increased amount of blood, but are unable to come to a decision. Two possibilities suggest themselves, first that the source is the residual blood; second that it is contributed by the ventricular walls as the result of more vigorous contraction, in consequence of which they drain themselves more completely of the blood in the capillaries and Thebesian veins, in the sense developed by Wearn (1928). In other dogs, if size and excursions returned simultaneously to normal, there was no overshooting of the cardiac output but a gradual and consistent return to normal (dog 257 (fig. 5), and dog 265: (fig. 3)) or toward normal (dog 266). The effects of digitalis on heart muscle are the same in all dogs, but the net result on the output from the ventricles depends upon which of the two effects described is the greater.

-The point which has just been discussed concerning the possibility of a critical relation betweer the size of the heart and its volume 
output, we have attempted to study by plotting systematically all the measurements of size that we have made in all the dogs and of correlating them with the corresponding simultaneous volume outputs (fig. 8). The sizes (not grouped from the point of view of their origin in individual dogs) are arranged in decreasing order (table 1, column 14 and table 3 , column 15). It will be observed that as the

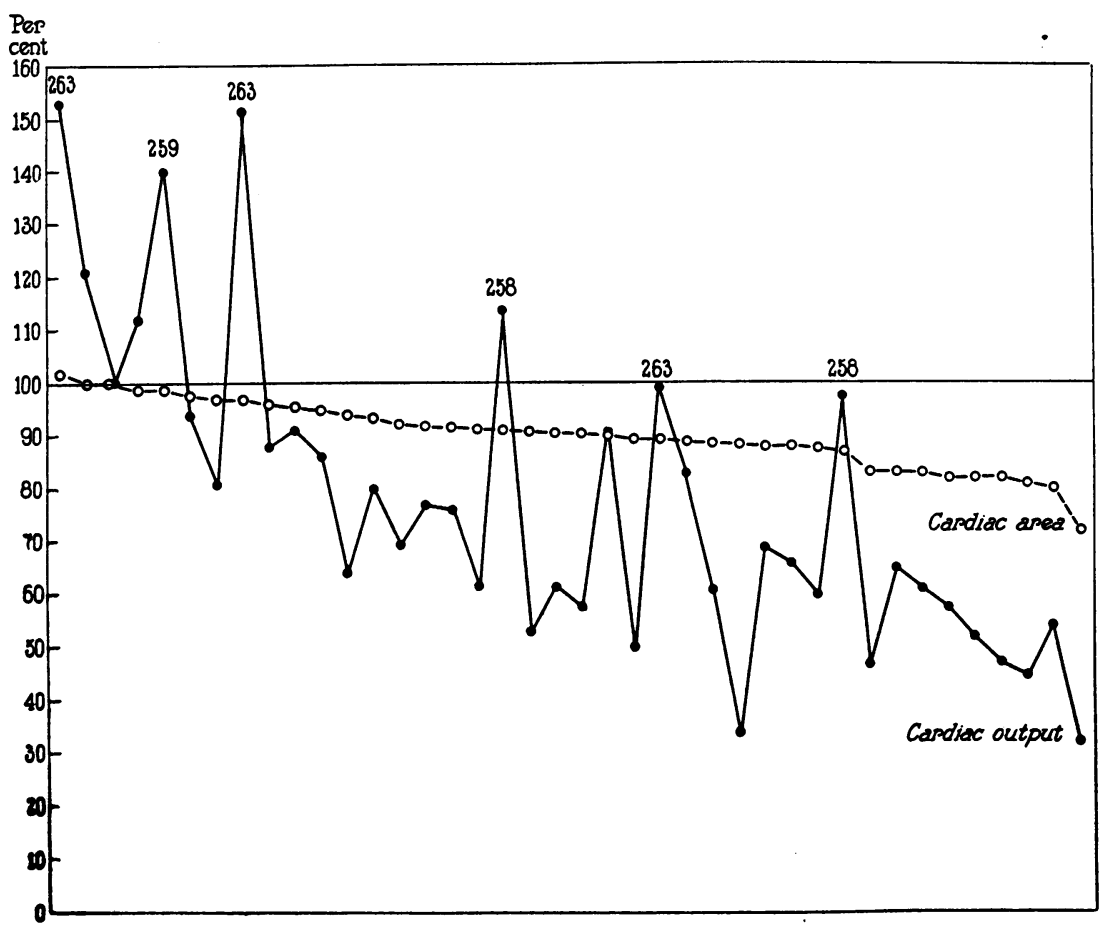

Fig. 8. Showing the Correlation Between Cardiac Size and Cardiac OUTPUT

For explanation see the text

areas of the hearts decrease, volume outputs also decrease consistently, though these naturally fluctuate. The slope of the curve of cardiac output is greater than that of heart area. The difference is to be expected since cardiac output is a cubic, while the heart area is a square measurement. Were it not that we have data on differences in the extent of the ventricular excursions we should be unable 
to explain the high peaks on the curve of cardiac output. These are higher because of that other effect of the action of digitalis, one namely on ventricular excursions which overbalances the effect of decrease in size and yields an end result so far as output is concerned greater than the size of the heart would lead one to expect.

These experiments confirm those of Harrison and Leonard (1926) and of Burwell, Neighbors and Regen (1927) in respect to the effect of digitalis on the output from the ventricles. We have, however, analyzed the result of giving digitalis further and have found reason for disagreeing with the inferences which they drew. We have been able to unravel a twofold action of digitalis. One is on the tone of the muscle from which issues a decrease in output. Unlike Harrison and Leonard we think that this result is plainly not the consequence of a sedative action, not depressant, but of an action which in effect is the reverse of this, is due in fact to an increase in tone and consists in making of the heart a smaller pump. The second effect is the action on contraction; this too can scarcely be regarded as sedative. Certainly, increasing the height of the excursions must be thought of as stimulation. The use of the term depressant used by Harrison and Leonard is not, it appears, descriptive of the action of digitalis on the functions of heart muscle which we have been able to analyze. To apply it to the output of hearts affected primarily by stimulating, augmenting, actions, may it seems to us lead to serious misunderstanding. Inferences which involve this idea should be reviewed when direct evidence becomes available, both in heart failure and in pneumonia. It is not without interest to recall the fact that this is not the first time that the action of digitalis has been regarded as sedative. Bouillaud (1835) in 1835 stated "ce médicament, comme je l'ai déjà dit, est le véritable opium du coeur."

Since the experiments described in this paper refer to the short fibered normal heart the conclusions to be drawn from them need not necessarily apply to extended, perhaps over-extended, fibers of the enlarged or diseased heart. The effect must be studied separately in each. We have accordingly proceeded to experiments on the enlarged heart and are reporting these in a second paper (Cohn and Stewart, 1928a). 


\section{SUMMARY}

The effect of therapeutic doses of digitalis given intravenously and by mouth upon the circulation of normal dogs has been studied. It was found that:

1. Changes in T-waves of the electrocardiograms were constantly observed.

2. The heart rate always slowed 2 to 3 hours after giving digitalis unless an abnormal rhythm developed. In 24 hours the rate was like the initial count.

3. The cardiac area decreased.

4. The ventricular excursions increased.

5. The cardiac output always decreased at first, but might later increase.

6. These effects were at a maximum 2 to 24 hours after the administration of the drug.

7. As the effect of digitalis wore off the cardiac output, cardiac size and ventricular excursions returned to normal. The cardiac output often became greater than the initial value.

\section{CONCLUSIONS}

Digitalis within the first 24 hours decreases the cardiac output of normal dogs. The cardiac output which obtains at any later instant is the net result of the working of two opposing factors. The first of these effects increases cardiac tone and results in decrease in the size of the heart. It is due to this action that cardiac output tends to decrease. The second effect increases ventricular contraction and tends to increase cardiac output. If cardiac size is not smaller than a critical value, increase in ventricular contraction overbalances decrease in size so that cardiac. output increases beyond the beginning value.

\section{BIBLIOGGRAPHY}

Blalock, A., Jour. Lab. and Clin. Med., 1927, xii, 378. A Rubber Mask for Determination of Oxygen Consumption of the Dog.

Bouillaud, J., Paris, 1835. Traité clinique des maladies du coeur.

Burwell, C. S., Neighbors, D., and Regen, E. M., Jour. Clin. Invest., 1927, v, 125. The Effect of Digitalis upon the Output of the Heart in Normal Man. 
Cohn, A. E., Unpublished Experiments.

Cohn, A. E., and Stewart, H. J., Jour. Clin. Invest., 1924, i, 97. Evidence that Digitalis Influences Contraction of the Heart in Man.

Cohn, A. E., and Stewart, H. J., (1928a) Proc. Soc. Exper. Biol. and Med., 1928, xxv, 304. Relation Between Cardiac Size and Cardiac Output per Minute Following Administration of Digitalis.

Cohn, A. E., and Stewart, H. J., (1928b) Jour. Clin. Invest., 1928, vi, 79. The Relation Between Cardiac Size and Cardiac Output per Minute Following the Administration of Digitalis in Dogs in Which the Heart is Enlarged.

Eyster, J. A. E., and Meek, W. J., Amer. Jour. Roent., 1920, vii, 471. Instantaneous Radiographs of the Human Heart at Determined Points in the Cardiac Circle.

Fick, A., Verhandl. d. physikal.-med. Gesellsch., Würzb. 1870. N. F. ii. S. xvi. der Sitzungsber. Ueber die Messung des Blutquantums in der Herzventrikeln.

Harrison, T. R., and Leonard, B. W., Jour. Clin. Invest., 1926, iii, 1. The Effect of Digitalis on the Cardiac Output of Dogs and Its Bearing on the Action of the Drug in Heart Disease.

Pardee, H. E. B., Jour. Amer. Med. Assoc., 1925, lxxxv, 1359. Hypodermic Digitalis Preparations.

Ropinson, G. C., and Wilson, F. N., Jour. Pharm. and Exper. Therap., 1918, x, 491. A Quantitative Study of the Effect of Digitalis on the Heart of the Cat.

Stewart, H. J., Jour. Biol. Chem., 1925, lxii, 641. The Oxygen and Carbon Dioxide Contents of the Arterial and Mixed Venous Blood in Normal Intact Dogs.

Stewart, H. J., Jour. Clin. Invest., 1927, iii, 475. A Technique for Measuring X-ray Photographs of the Cardiac Areas of Dogs.

Van Slyke, D. D., and Neill, J. M., Jour. Biol. Chem., 1924, lxi, 523. The Determination of Gases in Blood and Other Solutions by Vacuum Extraction and Manometric Measurement. I.

Wearn, J. T., Jour. Exper. Med., 1928, lxvii, 293. The Rôle of the Thebesian Vessels in the Circulation of the Heart. 